\title{
The determination of micro quantities of manganese in plant material
}

\section{J. CH. VAN SCHOUWENBURG and I. WALINGA}

State Agricultural University, Laboratory of Soils and Fertilizers, Wageningen, and Institute for Soil Fertility, Groningen, Netherlands

\section{Summary}

After a liquid-liquid extraction with 2-thenoyltrifluoroacetone, micro quantities of manganese in plant material can be determined with formaldoxime without interference from other elements.

\section{Introduction}

For research work on plant material it was necessary to develop a method for determining micro quantities of $\mathrm{Mn}$ in plant material with a very high $\mathrm{Fe}$ content.

One of the most sensitive determinations of $\mathrm{Mn}$ is a method in which $\mathrm{Mn}$ catalyses the oxidation of tetramethyldiaminodiphenylmethane (SiNGLE, 1957; CoRNFIELd and Pollard, 1950). As with all catalytic processes the method calls for a rigid temperature and time control. Nevertheless unaccountable variations associated with changes in the rate of colour development seem to occur (Single, 1957). Fe interferes and must be extracted in advance (SNELl and SNELl, 1959).

Another reaction catalyzed by $\mathrm{Mn}$ is the oxidation of leucomalachitegreen $\left(4,4^{\prime}\right.$-tetramethyldiaminetriphenylmethane). However, this very sensitive reaction (KocH and Koch-Sedic, 1964 ; Fernandez et al., 1963) is severely influenced by the presence of Fe (III). The procedure of Fernandez et al. (1963) is furthermore very time consuming because the extinction of each sample has to be measured five times at intervals of one hour. The slope of the extinction-time curve is a linear function of the Mn concentration.

1-(2-pyridylazo)-naphtol (PAN) was first proposed by CHENG and BRAY (1955) as a very sensitive reagent for the determination of several metals. BERGER and Elvers $(1959 / 60)$ and especially SHibata $(1960 ; 1961)$ have published on this subject.

It however proved not altogether possible to get reproducible results with the methods described. This can perhaps be attributed to acids contained in the chloroform which set free oxidation products that "bleach" the coloured Mn complex. This suggestion of BERGER and Elvers (1964) was however, at that moment, not known to the authors. The determination of $\mathrm{Mn}$ with formaldoxime is less sensitive than the methods mentioned above but it is much more sensitive than the permanganate method (PINTA, 1962; Sandell, 1959; Snell and Snell, 1959). According to Marczenko (1964) formaldoxime forms highly-coloured complexes with $\mathrm{Mn}, \mathrm{Fe}, \mathrm{Ni}, \mathrm{Ce}, \mathrm{V}, \mathrm{Cu}$ and $\mathrm{Co}$.

Received for publication 19th August, 1965. 
To test the interference of some of these metals spectrograms were made of $50 \gamma$ quantities of $\mathrm{Mn}, \mathrm{Fe}, \mathrm{Ni}$, $\mathrm{Co}$ and $\mathrm{Cu}$ with formaldoxime in a $\mathrm{NH}_{4} \mathrm{OH}$ medium at a final volume of $25 \mathrm{ml}$. These are presented in the FIGURE.

At $450 \mathrm{~nm}$, interference can be expected from $\mathrm{Fe}$ and $\mathrm{Ni}$. Contrary to the statement of MARCzenko, the influence of $\mathrm{Cu}$ and $\mathrm{Co}$ proved to be negligible at these concentrations. The level of $\mathrm{Co}, \mathrm{Ce}$ and $\mathrm{V}$ in plant material (PINTA, 1962) is so low that interferences by these elements are not to be expected.

The interference caused by $\mathrm{Ni}$ is readily masked by cyanide. The masking of high amounts of $\mathrm{Fe}$ however constitutes a problem because all the masking agents tested for this puspose resulted in the formation of a yellow-coloured complex which, in its turn, interferes. It was therefore necessary to separate the Fe from the $\mathrm{Mn}$. If this procedure is worked out in such a way that $\mathrm{Mn}$ is concentrated at the same time, the formaldoxime method can be applied to very low $\mathrm{Mn}$ levels.

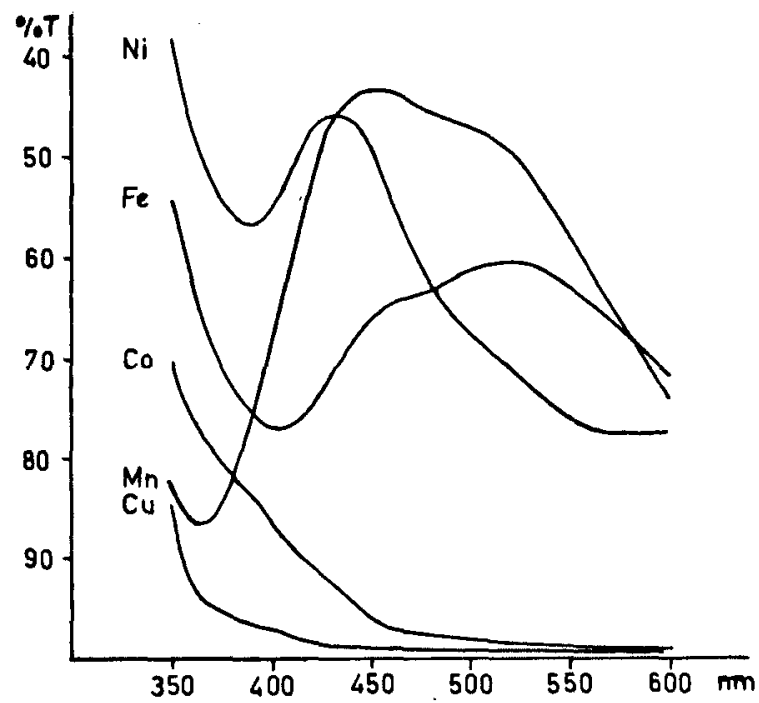

Figure

Spectrograms of $\mathrm{Mn}-$, Fe-, Ni-. $\mathrm{Co}$ - and $\mathrm{Cu}$-formaldoxime complexes

ECKERT (1955/56, 1957) and BODE and TUSCHKE (1957) use a sodium-diethyldithiocarbamate extraction in chloroform or carbontetrachloride. A back-extraction of the organic phase with a zinc solution liberates all of the $\mathrm{Mn}$ and only a small part of the Fe (BoDe and Tuschke, 1957). At a $1000: 1 \mathrm{Fe} / \mathrm{Mn}$ ratio the separation did not prove to be sufficiently selective.

It was tried to prevent the extraction of $\mathrm{Fe}$, under the circumstances mentioned above, by complexation with o-phenanthroline. At the high $\mathrm{pH}$ levels tested a part of the orange-coloured Fe complex allways contaminated the back-extraction phase. Washings with the medium used for the extraction of the $\mathrm{Mn}$ eliminated this contamination, but resulted in the loss of some $\mathrm{Mn}$.

Cheng (1961) mentions the use of 2-thenoyltrifluoroacetone (TTA) as a means of extracting $\mathrm{Mn}$ selectively at $\mathrm{pH} \mathrm{6-10}$ in the presence of tartrate with 4-methyl-2pentanone. According to this author only Co will accompany $\mathrm{Mn}$ and this can probably be prevented by triethylenetetramine. JOHNSON and LOTT (1963) extract Mn with 
TTA in a mixture of 2-octanon and 4-methyl-2-pentanone at $\mathrm{pH} \mathrm{8.} \mathrm{The} \mathrm{flamephoto-}$ metric determination of $\mathrm{Mn}$ directly in the organic phase is however influenced by $\mathrm{Ce}, \mathrm{Co}, \mathrm{Cr}, \mathrm{Fe}$ (II), (III), $\mathrm{Ni}$ and $\mathrm{Th}$. De and Rahaman (1963) extract the same complex in an acetone-benzene mixture at $\mathrm{pH}$ 6.7-8.0. Colour reactions are reported with $\mathrm{Cu}, \mathrm{Ni}, \mathrm{Cr}, \mathrm{U}$. Co interferes seriously. Fe is removed beforehand. The determination in the organic phase as proposed by these authors is not sensitive enough for our purpose.

It therefore seemed logical to back-extract the organic phase under slightly acidic circumstances. The iron will then stay in the organic phase (MORISON and FrEISER, 1957) whereas the $\mathrm{Mn}$ will be transferred into the water phase where it now can be determined with formaldoxime.

\section{Experiments}

The experiments were started using 4-methyl-2-pentanone as the organic phase. The separation of the two phases was however time consuming. A 1:1 mixture of the 4-methyl-2-pentanone with n-dibutylether led to a fast and clear separation of the two phases. It furthermore proved profitable, for the same reason, to introduce $\left(\mathrm{NH}_{4}\right)_{2} \mathrm{SO}_{4}$.

Because of the rather high $\mathrm{pH}$ tartrate was added to prevent precipitations.

An extraction with an acetone-benzene mixture as proposed by DE (1963) led to a turbid water phase under our circumstances. The yield of the extraction was as high as with the 4-methyl-2-pentanone and n-dibutylether mixture.

In the presence of tartrate and $\left(\mathrm{NH}_{4}\right)_{2} \mathrm{SO}_{4}$ the optimal $\mathrm{pH}$ for extraction was determined. The highest yield was obtained at $\mathrm{pH} 7.7-8.3$ but errors caused by a higher $\mathrm{pH}$ up to 8.8 were negligible.

The extraction of $20 \gamma$ of Mn was optimal after 2 minutes shaking using a shaking machine with a stroke of $9 \mathrm{~cm}$ and 150 oscillations/minute.

For the determination of Mn, van DEN HENDE and Cottenie (1960) use a metolsulphite-reducing agent. This mixture has a much longer shelf life as the more commenly used ascorbic acid. The back extraction of $\mathrm{Mn}$ into a water phase could readily be achieved with diluted $\mathrm{HNO}_{3}$ or $\mathrm{H}_{2} \mathrm{SO}_{4}$. To cut down on the number of additions this acid was mixed with the metol-sulphite-reducing agent. Lower blanks could, in this case, be obtained with $\mathrm{H}_{2} \mathrm{SO}_{4}$ as compared with other acids tested $\left(\mathrm{HCl}\right.$ and $\left.\mathrm{HNO}_{3}\right)$.

A shaking time of three minutes sufficed for a reproducible extraction.

The back-extracted $\mathrm{Mn}$ was determined with formaldoxime according to the method described by van den Hende and CotTenie (1960).

\section{Reagents}

Only analytical grade chemicals have been used.

a. metol-sulphite-sulphuric-acid solution: $\operatorname{mix}$ before use equal volumes of reagents a.1 and a.2.

a.1. dissolve $34 \mathrm{~g}$ of $\mathrm{Na}_{2} \mathrm{~S}_{2} \mathrm{O}_{5}, 2.5 \mathrm{~g}$ of $\mathrm{Na}_{2} \mathrm{SO}_{3} .7$ aq and $0.25 \mathrm{~g}$ of metol (pmethylaminophenolsulphate) and make up to a volume of $500 \mathrm{ml}$.

a.2. diluted sulphuric acid: dilute $14 \mathrm{ml}$ of $\mathrm{H}_{2} \mathrm{SO}_{4}$ (s.w. 1.84) to a final volume of 1 litre. 
b. buffer solution: dissolve $50 \mathrm{~g}$ of $\mathrm{KNa}$ tartrate. $4 \mathrm{aq}, 125 \mathrm{~g}$ of $\left(\mathrm{NH}_{4}\right)_{2} \mathrm{SO}_{4}$ and $10 \mathrm{ml}$ of $\mathrm{NH}_{4} \mathrm{OH}$ (s.w. 0.91 ) and make up to a final volume of 1 litre.

c. TTA solution: dissolve $3.3 \mathrm{~g}$ of 2-thenoyltrifluoroacetone in 1 litre of a $1+1$ mixture of n-dibutylether and 4-methyl-2-pentanone. This solution can be stored for at least one month.

d. alkaline $\mathrm{KCN}$ solution: dissolve $1.7 \mathrm{~g}$ of $\mathrm{KCN}$ and $22.4 \mathrm{ml}$ of $\mathrm{NH}_{4} \mathrm{OH}$ (s.w. 0.91) and make up to a final volume of $100 \mathrm{ml}$.

e. formaldoxime reagent: dissolve $5 \mathrm{~g}$ of hydroxylamine- $\mathrm{HCl}$ and $5 \mathrm{~g}$ of formaldehyde $40 \%$ and make up to a final volume of $100 \mathrm{ml}$.

f. ammonia $1.6 \mathrm{n}$ : dilute $12 \mathrm{ml} \mathrm{NH} \mathrm{NH}_{4} \mathrm{OH}$ (s. 0.91 ) and make up to a final volume of $100 \mathrm{ml}$.

g. standard solution of $10 \mathrm{ppm} \mathrm{Mn}$ : dissolve in a $600-\mathrm{ml}$ beaker $0.288 \mathrm{~g}$ of $\mathrm{KMnO}_{4}$ in about $200 \mathrm{ml}$ of distilled water to which has been added $45 \mathrm{ml}$ of $\mathrm{H}_{2} \mathrm{SO}_{4}$ s.w. 1.84). Reduce the $\mathrm{KMnO}_{4}$ with a few drops of $\mathrm{H}_{2} \mathrm{O}_{2} 30 \%$. Boil to expel the excess of $\mathrm{H}_{2} \mathrm{O}_{2}$. Rinse the cooled solution into a 1-litre volumetric flask and make up to volume. Pipette $100 \mathrm{ml}$ of this solution into a 1-litre volumetric flask and make up to volume.

\section{Procedure}

Digestion of the organic material (SchaumlöFfel, 1960): Weigh out $1 \mathrm{~g}$ of air-dry plant material in a $50-\mathrm{ml}$ volumetric flask. Next add $10 \mathrm{ml}$ of an acid mixture ( $\mathrm{HNO}_{3}: \mathrm{HClO}_{4}: \mathrm{H}_{2} \mathrm{SO}_{4}=10: 1: 0.25$ volume parts) and, if possible, keep overnight to prevent excessive foaming. Heat moderately on a hotplate. It should take 40 minutes or more for the $\mathrm{HNO}_{3}$ to evaporate. Afterwards the heat is raised to full. Destruction is complete when only the sulphuric acid is left. If a colour persists, the flask should be cooled and some drops of $\mathrm{HClO}_{4} 60 \%$ added. Reheat the flask until all the $\mathrm{HClO}_{4}$ is evaporated. Add $10-20 \mathrm{ml}$ of distilled water and some drops of $\mathrm{H}_{2} \mathrm{O}_{2} 30 \%$ to reduce $\mathrm{Mn}$ oxides which might have formed, and boil during 10 minutes. (BradFIELD (1964) suggests the use of $\mathrm{NaNO}_{2}$ for this purpose which seems a better approach since traces of $\mathrm{H}_{2} \mathrm{O}_{22}$ might interfere with other determinations in the same digest). Cool the flasks and fill up to the mark with distilled water.

Determination of the manganese:

Pipette $5-10-20$ or $35 \mathrm{ml}$ of the digest (containing less than $20 \gamma$ of $\mathrm{Mn}$ ) into a separating funnel. Then add $10 \mathrm{ml}$ of buffer solution and bring to $\mathrm{pH} 7.8-8.8$ with ammonia $1.6 \mathrm{n}(1 \mathrm{ml}$ of ammonia $1.6 \mathrm{n}$ for each $10 \mathrm{ml}$ of digested sample serves the purpose). Add distilled water to a total volume of $50 \mathrm{ml}$. Add $20 \mathrm{ml}$ of TTA solution and shake mechanically during 2 minutes (stroke length $9 \mathrm{~cm}, 150$ oscillations/minute). Wait until the phases have separated and discard the water phase. Next, add to the organic phase $4 \mathrm{ml}$ of the metol-sulphite-sulphuric-acid mixture and shake on a mechanical shaker for 3 minutes. Wait until the phases have separated and leave off the water phase, quantitatively, into test tubes. Add to the contents in the test tubes $1 \mathrm{ml}$ of the alkaline $\mathrm{KCN}$ solution and 3 drops of the formaldoxime reagent respectively. Wait 30 minutes and filter the solution before measurement in $1-\mathrm{cm}$ cuvettes at $450 \mathrm{~nm}$. 
TABLE 1. Reproducibility of added manganese

\begin{tabular}{crrrrrrrr}
\hline $\begin{array}{c}\gamma \text { of Mn } \\
\text { added }\end{array}$ & \multicolumn{10}{c}{$\gamma$ of Mn recovered } & & & \\
5 & 5.1 & 5.0 & 4.9 & 5.2 & 5.0 & 4.8 & & \\
10 & 9.7 & 9.9 & 9.9 & 9.7 & 9.3 & 10.0 & 10.1 & 10.2 \\
& 10.0 & 9.8 & 9.5 & 9.9 & & & & \\
20 & 19.8 & 20.6 & 21.0 & 20.8 & 20.0 & & & \\
\hline
\end{tabular}

\section{Interferences}

No interferences within experimental error were found with $4000 \gamma$ of Fe (II) or Fe (III), $20 \gamma$ of $\mathrm{Co}, 500 \gamma$ of $\mathrm{Cu}$ and $500 \gamma$ of $\mathrm{Ni}$ with the determination of $10 \gamma$ of $\mathrm{Mn}$. Part of the $\mathrm{Fe}$ originally present accompanied the $\mathrm{Mn}$ in the organic phase but it was back extracted to a negligible fraction which could easily be masked by the $\mathrm{KCN}$ present.

Co interfered (about $14 \%$ ) at the $100 \gamma$ level. Following CHENG's suggestion (1961), triethylenetetramine was tried as a masking agent for Co. $0.4 \mathrm{ml}$ of a $1+9$ diluted triethylenetetramine solution masked the Co influence at the $100 \gamma$ level but $200 \gamma$ of $\mathrm{Co}$ had a positive influence on the results (about $6 \%$ ). No further work was done on this point because higher quantities of $\mathrm{Co}$ are not expected in plant material.

The iron salt used for testing the interference of $\mathrm{Fe}\left(\mathrm{FeCl}_{3} .6 \mathrm{aq}\right)$ appeared to be contaminated with some $\mathrm{Mn}$. The iron was therefore separated by a liquid-liquid extraction with ether from a $6 \mathrm{n} \mathrm{HCl}$ medium and back extracted in $1.2 \mathrm{n} \mathrm{HCl}$.

\section{Reproducibility}

The results follow BeER's law up to at least $20 \gamma$ of $\mathrm{Mn}$. The blank, under our circumstances, varied between $0.030-0.070$ extinction units, depending on the shelflife of the reagents.

Considering the minor quantities involved, the reproducibility of the method is satisfactory, as shown in TABLE 1. Applied to the determination of $\mathrm{Mn}$ in plant material the results proved to be satisfactory. Different quantities of plant material with and without an addition of $\mathrm{Mn}$ have been wet-ashed with $20 \mathrm{ml}$ of a $10: 1: 0.25 \mathrm{v} / \mathrm{v}$

TABLE 2. Mn content (ppm) of plant material after wet ashing of $0.5,1.0$ and $1.0 \mathrm{~g}$ of plant material with $\mathrm{Mn}$ added

\begin{tabular}{|c|c|c|c|}
\hline & $0.5 \mathrm{~g}$ & $1.0 \mathrm{~g}$ & $1.0 \mathrm{~g}+\mathrm{Mn}$ \\
\hline Potato tubers & 8.1 & 8.4 & 9.0 \\
\hline Peas $\ldots \ldots$ & 15 & 15 & 15 \\
\hline Barley grain & 21 & 21 & 22 \\
\hline Apple leaves & 37 & 37 & 36 \\
\hline Cucumber leaves & 41 & 41 & 40 \\
\hline Valeriana officinalis & 74 & 72 & 72 \\
\hline Grass ........... & 88 & 89 & 86 \\
\hline Oats straw & 146 & 148 & - \\
\hline
\end{tabular}


mixture of $\mathrm{HNO}_{3}, \mathrm{HClO}_{4}, \mathrm{H}_{2} \mathrm{SO}_{4}$ respectively. After subtraction of the $\mathrm{Mn}$ added, the results are as presented in TABLE 2 .

BERGER, W., and

H. Elvers

and

BODE, H., and

K. J. TuschKE

BRADFIELD, E. G.

Cheng, K. L.

Cheng, K. L., and R. H. BRAY

CORNFIELD, A. H., and A. G. Pollard

DE, A. K., and M. S. Rahaman

ECKERT, G.

Fernandez, A. A., Ch. Sobel, and S. L. J ACOBS

Goto, K., T. Komatsu, and T. Furukawa

HENDE, A. VAN DEN, and A. H. CottenIE

JOHNSON, D. A., and P. F. LOTT

KNiphorst, L. C. E.

Koch, O. G., and G. A. Koch-Dedic Marczenko, $Z$.

\section{REFERENCES}

1959/60 Qualitative Kationenanalyse unter Verwendung von Metallindikatoren. Il. Untersuchungen mit Pyridylazonaphtol (PAN). Z. anal. Chem. 17l, 185.

1964 PAN als photometrisches Reagenz. II. Bestimmung von Zink und Cadmium in Reinkupfer. Z. anal. Chem. 199, 166.

1957 Untersuchungen über disubstituierte Dithiocarbaminate. VI. Verdrängungsreaktionen zwischen innerkomplexen Metall-Diäthyldithiocarbaminaten in organischer Phase und Metall-ionen in wässriger Phase. $Z$. anal. Chem. J57, 414.

1957 An improved formaldoxime method for the determination of manganese in plant material. The Analyst. 82, 254.

1964 Leaf analysis as a guide to the nutrition of fruit crops. IV. Scheme for the rapid determination of copper, iron, manganese and zinc in plant material. J. Sci. Fd Agric. 15, 469.

1961 Increasing sensitivity of analytical reactions by masking. Anal. Chem. 33, 783.

1955 1-(2-pyridylazo)-2-naphtol as a possible analytical reagent. Anal. Chem. 27, 782.

1950 The use of tetramethyldiaminodiphenylmethane for the determination of small amounts of manganese in plant material and soil extracts. J. Sci. Fd Agric. 1, 107.

1963 Rapid extraction of manganese (II) with 2-thenoyltrifluoroacetone. Spectrophotometric determination in the organic phase. Anal. Chem. 35, 159.

1955/56 Analyse von Nickellegierungen für Oxydkathoden. 2 Mitt. Bestimmung des Mangans. Z. anal. Chem. 148, 14.

1957 Ein Beitrag zur Anwendung disubstituierter Dithiocarbaminat Verbindungen für analytische Trennungen. $Z$. anal. Chem. $155,23$.

1963 Sensitive method for the determination of submicrogram quantities of manganese and its application to human serum. Anal. Chem. 35, 1721.

1962 Rapid colorimetric determination of manganese in waters containing iron. Anal. Chim. Acta. 27, 331.

1960 L'estimation de la fertilité du sol par les méthodes chimiques nouvelles. Travaux du Centre de Chimie Physique Agricole. No. 25. I.R.S.I.A. Bruxelles.

1963 Flame photometric determination of manganese in copper and steel alloys. Anal. Chem. 35, 1705.

1946 Gecombineerde bepaling van het gehalte aan ijzer en mangaan in voedingsmiddelen met behulp van sulfosalicylzuur en formaldoxime. Chem. Weekbl. 42, 311, 328.

1964 Handbuch der Spurenanalyse. Springer Verlag, Berlin, p. 1232

1964 Dosage spectrophotométrique de différents métaux $(\mathrm{Mn}, \mathrm{Ce}$, $\mathrm{V}, \mathrm{Ni}, \mathrm{Fe}$ ) au moyen de la formaldoxime. Anal. Chim. Acta. $31,224$. 
Morison, G. H., and H. FREISER

Pinta, M.

SANDELL, E. B.

SchaumlöFFEL, E.

Shibata, $\mathbf{S}$.

Single, W. V.

SNELL, F. D., and

C. T. SNELL
1957 Solvent extraction in analytical Chemistry. John Wiley \& Sons, Inc., New York. p. 269.

1962 Recherche et dosage des éléments traces. Dunod. Paris. p. 726.

1959 Colorimetric determination of traces of metals. Interscience Publishers Inc. New York. p. 1032.

1960 Uber die colorimetrische Bestimmung der Mikronährstoffe Kupfer, Zink, Kobalt, Mangan, Eisen und Molybdän aus einer Aschenlösung durch fraktionierte Extraktion. Landw. Forsch. 13, 278.

1960 Solvent extraction behavior of some metal-1-(2-pyridylazo)-2naphtol chelates. Anal. Chim. Acta. 23, 367.

1961 Solvent extraction and spectrophotometric determination of metals with 1-(2-pyridylazo)-2-naphtol. Anal. Chim. Acta. 25, 348.

1957 Colorimetric estimation of manganese. Nature. 180, 250.

1959 Colorimetric methods of analysis. D. van Nostrand Company, Inc. New York. p. 793. 